Article

\title{
Flavonoids from Morus alba L. Leaves: Optimization of Extraction by Response Surface Methodology and Comprehensive Evaluation of Their Antioxidant, Antimicrobial, and Inhibition of $\alpha$-Amylase Activities through Analytical Hierarchy Process
}

\author{
Hao Cui ${ }^{1,2}$, Tenghui Lu ${ }^{1}$, Mingxin Wang ${ }^{1}$, Xintong Zou ${ }^{1}$, Yang Zhang ${ }^{1}$, Xiudong Yang ${ }^{1}$, \\ Yao Dong ${ }^{3, *}$ and Hongli Zhou ${ }^{1,2, *}$ \\ 1 School of Chemistry and Pharmaceutical Engineering, Jilin Institute of Chemical Technology, \\ Jilin 132022, China \\ 2 Engineering Research Center for Agricultural Resources and Comprehensive Utilization of Jilin Provence, \\ Jilin Institute of Chemical Technology, Jilin 132022, China \\ 3 College of Biology \& Food Engineering, Jilin Institute of Chemical Technology, Jilin 132022, China \\ * Correspondence: dy6224760@163.com (Y.D.); zhouhongli@jlict.edu.cn (H.Z.); \\ Tel.: +86-432-62185246 (Y.D. \& H.Z.)
}

Academic Editors: Maria Lisa Clodoveo and Filomena Corbo Received: 18 May 2019; Accepted: 26 June 2019; Published: 28 June 2019

\begin{abstract}
To explore the flavonoids from Morus alba L. leaves (MLF), the process of extracting was optimized by a response surface methodology and the antimicrobial and antioxidant activities were evaluated in vitro. The yield of flavonoids reached $50.52 \mathrm{mg} \mathrm{g}^{-1}$ under the optimized extraction conditions (i.e., extraction temperature, $70.85{ }^{\circ} \mathrm{C}$; solvent concentration, $39.30 \%$; extraction time, $120.18 \mathrm{~min}$; and liquid/solid ratio, 34.60:1). The total flavonoids were extracted in organic solvents with various polarities, including petroleum ether $\left(M_{L} F_{p}\right)$, ethyl acetate $\left(M_{L} F_{e}\right)$, and $n$-butanol $\left(\mathrm{MLF}_{\mathrm{b}}\right)$. In vitro, the four MLF samples exhibited good antioxidant activities for scavenging of 2, 2'-azinobis-(3-ethylbenz-thiazoline-6-sulphonate) radical, 1, 1-diphenyl-2-picrylhydrazyl radical, and total reducing power. Regarding antimicrobial efficacy, the MLF samples suppressed the development of Staphylococcus aureus, Bacillus subtilis, and Bacillus pumilus. The MLF samples inhibited $\alpha$-amylase activity to a certain extent. The analytical hierarchy process (AHP) was used to evaluate comprehensively the bioactivities of the MLF samples. The AHP results revealed that the bioactivity comprehensive score $\left(78.83 \mu \mathrm{g} \mathrm{mL}^{-1}\right)$ of $\mathrm{MLF}_{\mathrm{e}}$ was optimal among the four MLF samples. Morus alba L. leaves also exhibited non-hemolytic properties. All bioactivities suggested the potential of $\mathrm{MLF}_{\mathrm{e}}$ as a candidate resource in the food and drug industries.
\end{abstract}

Keywords: mulberry leaves; flavonoids; optimization; extraction conditions; in vitro; bioactivities; AHP; evaluate comprehensively

\section{Introduction}

Morus alba L. (mulberry) leaves are used in traditional medicine and were even recognized as edible, medicinal substances in 1993 by the Ministry of Health of the People's Republic of China. Extracts of mulberry leaves contain a series of bioactivity products, including flavonoids, $\gamma$-aminobutyric acid, 1-deoxynojirimycin, and chlorophyll [1]. Flavonoids contain active hydrogen, which can terminate the chain reaction of oxygen radicals, scavenge free radicals, and eliminate the toxic effect of radicals [2]. These flavonoids' antioxidation, anti-hyperlipidemia, anti-fatigue, anti-aging, and atherosclerosis-prevention activities have previously been reported. For example, $\mathrm{Li}$ [3] confirmed that 
flavonoids extracted from mulberry leaves with $60 \%$ ethanol solution have anti-fatigue activity in mice. Katsube [4] extracted compounds containing three flavonol glycosides with low density-lipoprotein antioxidant activity and found that quercetin3-(6-malonylglucoside) and rutin are the main flavonol glycosides in mulberry leaves. Kim [5] found that the water-extraction abilities of mulberry leaves containing four flavonols followed the order quercetin-3- $\beta$-D-glucose $>$ quercetin-3-O-glucose-6-acetate $>$ rutin $>$ quercetin. Compared with its glycosides, quercetin exhibited a stronger cellular antioxidant capacity against 2,2-azobis (2-amidinopropane) dihydrochloride and $\mathrm{Cu}^{2+}$-induced oxidative stress in HepG2 cells.

Flavonoids are also well known for their antimicrobial activity. The antimicrobial capacity and antibiotic spectra of flavonoids vary because their components originate from different sources. Liu [6] found seven purified flavonoids from Halostachys capsica exhibiting various antimicrobial capacities for eight microorganisms through minimal inhibitory concentration (MIC). Santas [7] found that quercetin and kaempferol inhibit Gram-positive bacteria, such as Bacillus cereus, Staphylococcus aureus, Microcroccus luteus, and Listeria monocytogenes. Conversely, Gram-negative ones, such as Escherichia coli and Pseudomonas aeruginosa, are less sensitive to their antimicrobial effect, and Candida albicans is totally resistant.

The flavonoids of luteolin, myricetin, and quercetin are potent inhibitors of $\alpha$-amylase, whose activity is related to substitution, such as 2,3-double bond, 5-OH, and the linkage of the B ring at the 3-position [8]. Lo [9] revealed the relationship of the structure and activity of $\alpha$-amylase inhibitors by molecular docking, and results show that the inhibitory activity of flavonoids relies on hydrogen bonds among the hydroxyl groups of polyphenol ligands, the catalytic residues of the binding site, and the formation of a conjugated $\pi$-system that stabilizes the interaction with the active site.

The extraction of flavonoids from mulberry leaves is usually carried out through ethanol extraction, ultrasonic extraction, and microwave extraction. Zhang [10] optimized the ethanol extraction of flavonoids from mulberry leaves through a response surface methodology (RSM) and confirmed the optimal process, namely, an ethanol concentration of $71.75 \%$, a temperature of $67.1^{\circ} \mathrm{C}$, liquid/solid ratio of 23.2:1, and a time of $150 \mathrm{~min}$. Under these conditions, the flavonoids yield was $2.37 \%$. Wang [11] found a flavonoid yield of $3.50 \%$ under the following conditions: ethanol concentration, $70 \%$; liquid/solid ratio, 50:1; time, $90 \mathrm{~min}$; and temperature, $80^{\circ} \mathrm{C}$.

The analytical hierarchy process (AHP) is a multi-criterion quantitative analysis technique to solve complex problems of multiple objectives [12]. In this methodology, the issue is resolved in a hierarchy structure, consisting of high, middle, and low levels. The elements in these levels are compared in pairs [13]. Hence, the relative preference is assessed with respect to each element at the next and higher level, based on the subjective judgment of experts. Further mathematical treatment is used to increase the scientific nature.

In the present study, a hot-reflux method was used, and the extraction process was optimized by RSM through single-factor experiment. In vitro activities, including antibacterial, antioxidant, and $\alpha$-amylase inhibition, of different flavonoids from dried, mature Morus alba L. leave samples (MLF) were analyzed. Multiple-bioactivities of MLF samples were evaluated by AHP. The hemolytic property of $\mathrm{MLF}_{\mathrm{e}}$ was determined to investigate its initial toxicity. Results indicated the potential application of $\mathrm{MLF}_{\mathrm{e}}$ in the food and drug industries.

\section{Results}

\subsection{Evaluation of Single Factors Affecting MLF Extraction}

The effects of various temperatures $\left(40-80^{\circ} \mathrm{C}\right)$ on MLF extractions were examined, and the results are presented in Figure 1A. The highest yield was $70{ }^{\circ} \mathrm{C} ; \mathrm{Y}_{\mathrm{MLF}}$ increased from $11.87 \pm 1.43 \mathrm{mg} \mathrm{g}^{-1}$ to $46.25 \pm 1.49 \mathrm{mg} \mathrm{g}^{-1}$ at $40-70{ }^{\circ} \mathrm{C}$ and then decreased to $26.51 \pm 1.45 \mathrm{mg} \mathrm{g}^{-1}$ at $80^{\circ} \mathrm{C}$. The optimum temperature for flavonoid extraction was deemed to be $70^{\circ} \mathrm{C}$. 
Given the high solubility of flavonoids in ethanol, it was used as an extraction solvent. To further research the effect of ethanol concentration on extraction yield, different concentrations from $20 \%$ to $60 \%$ were tested. Figure $1 \mathrm{~B}$ shows the effect of solvent on $\mathrm{Y}_{\mathrm{MLF}}$. The yield of MLF increased from $20 \%$ to $40 \%$ and reached a peak of $45.60 \pm 1.73 \mathrm{mg} \mathrm{g}^{-1}$ at $40 \%$ concentration, but obviously decreased at $40 \%$ to $60 \%$. Accordingly, $40 \%$ ethanol was chosen for succeeding experiments.

To investigate the effect of extraction time on $\mathrm{Y}_{\mathrm{MLF}}$, extraction was carried out at 60-180 min. As shown in Figure 1C, from $60 \mathrm{~min}$ to $120 \mathrm{~min}$, the yield prominently increased from $33.94 \pm 1.97$ to $44.64 \pm 1.19 \mathrm{mg} \mathrm{g}^{-1}$, and then leveled off. Accordingly, $120 \mathrm{~min}$ was used for RSM tests.

The liquid/solid ratio was also investigated. Figure 1D shows the extraction results in different liquid/solid ratios. Extraction efficiency increased with an increased liquid/solid ratio, especially from $27.19 \pm 1.57 \mathrm{mg} \mathrm{g}^{-1}(10: 1)$ to $47.50 \pm 1.26 \mathrm{mg} \mathrm{g}^{-1}$ (30:1), and then leveled off. Thus, the liquid/solid ratio of 30:1 was selected for subsequent experiments.
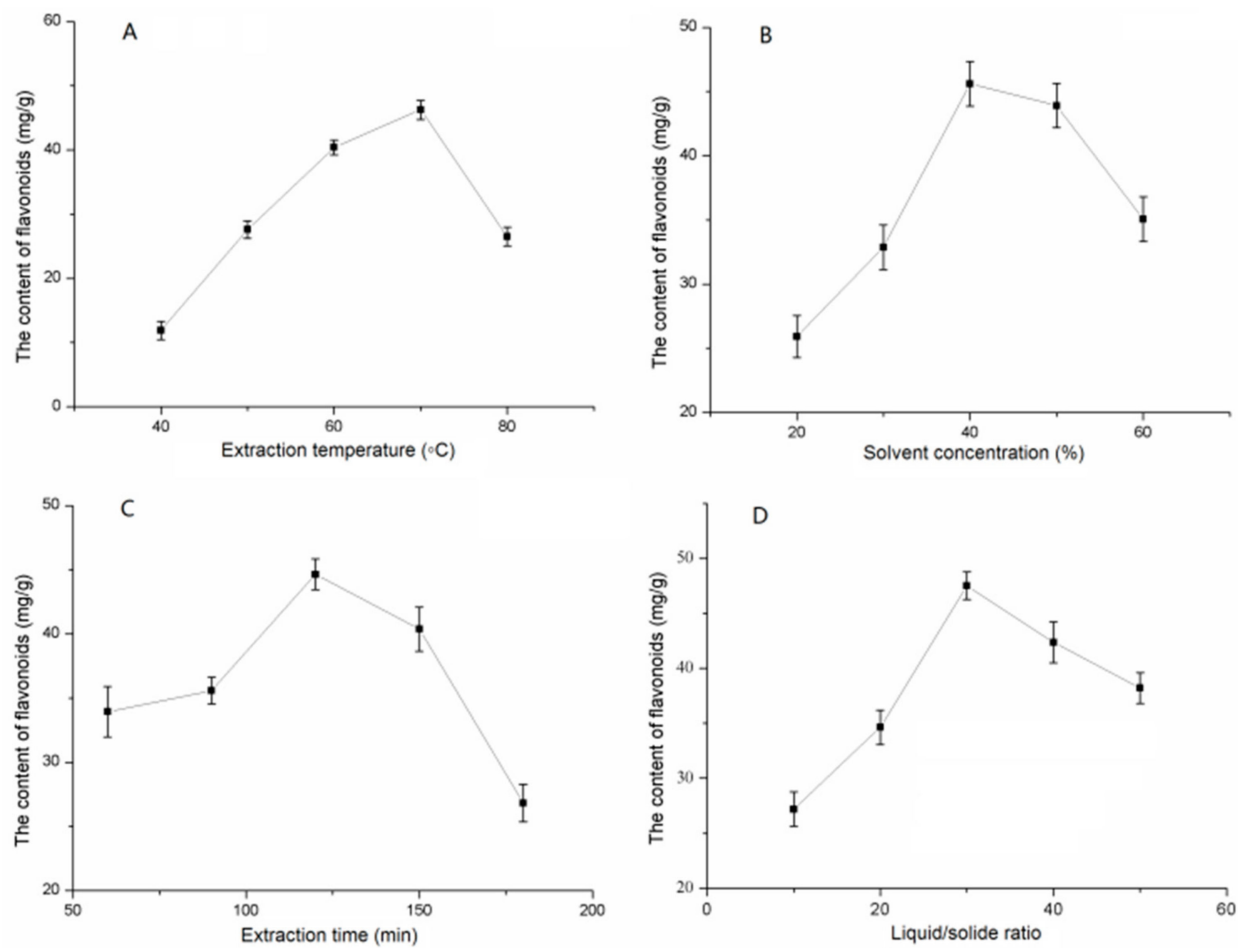

Figure 1. The effect of single factors on the extraction of Morus alba L. leaves (MLF). (A) Extraction temperature $\left({ }^{\circ} \mathrm{C}\right) ;(\mathbf{B})$ solvent concentration $(\%) ;(\mathbf{C})$ extraction time (min); (D) liquid/solid ratio. Data are shown as mean $\pm \mathrm{SD}(n=3)$.

\subsection{RSM Analysis}

The extraction of flavonoids was optimized by RSM. Table 1 shows the coded and actual levels used in the optimization process. A total of 29 tests were designed, including 5 zero-point experiments and 24 factorial tests.

Table 1. Coded and actual levels of independent variables used in the RSM.

\begin{tabular}{ccccc}
\hline \multirow{2}{*}{ Independent Variables } & Symbol & \multicolumn{3}{c}{ Coded Levels } \\
\cline { 3 - 5 } & & $\mathbf{- 1}$ & $\mathbf{0}$ & $\mathbf{+ 1}$ \\
\hline Extraction temperature $\left({ }^{\circ} \mathrm{C}\right)$ & $\mathrm{A}$ & $60{ }^{\circ} \mathrm{C}$ & $70{ }^{\circ} \mathrm{C}$ & $80{ }^{\circ} \mathrm{C}$ \\
Solvent concentration & $\mathrm{B}$ & $30 \%$ & $40 \%$ & $50 \%$ \\
Extraction time (min) & $\mathrm{C}$ & 90 & 120 & 150 \\
Liquid/solid ratio & $\mathrm{D}$ & $20: 1$ & $30: 1$ & $40: 1$ \\
\hline
\end{tabular}


Table 2 shows the designed and experimental data of the MLF. The $\mathrm{Y}_{\mathrm{MLF}}$ ranged within 30.98-50.50 $\mathrm{mg} \mathrm{g}^{-1}$. By the multivariable regression fitting method of the data in Table 2 , the quadratic polynomial regression model of extraction temperature $(A)$, solvent concentration $(B)$, extraction time $(C)$ and liquid/solid ratio $(D)$ were generated as shown in the equation blow:

$$
\begin{aligned}
R_{1} & =49.20+0.31 A-0.24 B+1.12 C+4.81 D+2.40 A B-4.47 A C+2.29 A D \\
& -0.66 B C-0.67 B D-1.61 C D-6.87 A^{2}-2.41 B^{2}-4.37 C^{2}-5.48 D^{2}
\end{aligned}
$$

\begin{tabular}{|c|c|c|c|c|c|c|}
\hline Run & $\begin{array}{c}\text { Coded Solvent } \\
\text { Concentration } \\
\text { Variable }\end{array}$ & $\begin{array}{c}\text { Coded } \\
\text { Liquid/Solid } \\
\text { Ratio Variable }\end{array}$ & $\begin{array}{l}\text { Coded Time } \\
\text { Variable }\end{array}$ & $\begin{array}{c}\text { Coded } \\
\text { Temperature } \\
\text { Variable }\end{array}$ & $\begin{array}{l}\text { Predicted Value } \\
\left(\mathrm{mg} \mathrm{g}^{-1}\right)\end{array}$ & $\begin{array}{l}\text { Actual Value } \\
\quad\left(\mathrm{mg} \mathrm{g}^{-1}\right)\end{array}$ \\
\hline 1 & 0 & +1 & -1 & 0 & 41.73 & 40.84 \\
\hline 2 & 0 & -1 & 0 & -1 & 36.08 & 34.01 \\
\hline 3 & +1 & -1 & 0 & 0 & 38.07 & 40.81 \\
\hline 4 & +1 & 0 & 0 & -1 & 30.06 & 30.98 \\
\hline 5 & -1 & 0 & 0 & -1 & 34.03 & 34.71 \\
\hline 6 & 0 & 0 & 0 & 0 & 49.20 & 48.17 \\
\hline 7 & -1 & 0 & -1 & 0 & 32.06 & 32.84 \\
\hline 8 & 0 & 0 & -1 & +1 & 44.65 & 46.35 \\
\hline 9 & +1 & 0 & 0 & +1 & 44.26 & 44.00 \\
\hline 10 & 0 & 0 & +1 & +1 & 43.67 & 43.91 \\
\hline 11 & -1 & 0 & 0 & +1 & 39.06 & 38.56 \\
\hline 12 & 0 & 0 & 0 & 0 & 49.20 & 48.26 \\
\hline 13 & -1 & +1 & 0 & 0 & 36.98 & 35.24 \\
\hline 14 & 0 & +1 & +1 & 0 & 42.66 & 43.76 \\
\hline 15 & 0 & +1 & 0 & +1 & 45.22 & 45.89 \\
\hline 16 & 0 & -1 & -1 & 0 & 40.88 & 40.19 \\
\hline 17 & -1 & 0 & +1 & 0 & 43.24 & 43.49 \\
\hline 18 & 0 & -1 & +1 & 0 & 44.44 & 45.75 \\
\hline 19 & 0 & 0 & 0 & 0 & 49.20 & 48.79 \\
\hline 20 & 0 & -1 & 0 & +1 & 47.03 & 45.20 \\
\hline 21 & +1 & 0 & +1 & 0 & 34.92 & 32.73 \\
\hline 22 & +1 & 0 & -1 & 0 & 41.62 & 39.97 \\
\hline 23 & 0 & 0 & -1 & -1 & 31.81 & 32.57 \\
\hline 24 & 0 & +1 & 0 & -1 & 36.95 & 37.37 \\
\hline 25 & +1 & +1 & 0 & 0 & 42.40 & 42.85 \\
\hline 26 & 0 & 0 & 0 & 0 & 49.20 & 50.50 \\
\hline 27 & -1 & -1 & 0 & 0 & 42.26 & 42.81 \\
\hline 28 & 0 & 0 & +1 & -1 & 37.28 & 36.59 \\
\hline 29 & 0 & 0 & 0 & 0 & 49.20 & 50.30 \\
\hline
\end{tabular}

Table 2. Response surface design and experimental data.

The analysis of variance (ANOVA) for the regression equation is shown in Table 3, with $p<0.05$, the linear coefficient $(C$ and $D)$, the quadratic coefficients $\left(A^{2}, B^{2}, C^{2}\right.$, and $\left.D^{2}\right)$, and the interaction coefficients $(A B, A C$, and $A D)$ having significant effects. The others, namely, $A, B, B C, B D$, and $C D$ with $p>0.05$, had insignificant effects. Furthermore, the influence of the conditions on $\mathrm{Y}_{\mathrm{MLF}}$ followed the sequence liquid/solid ratio $(D)$, extraction time $(C)$, extraction temperature $(A)$, and solvent concentration $(B)$.

Table 3. Variance analysis of extracted equation of flavonoids from mulberry leaves.

\begin{tabular}{cccccc}
\hline Source & Sum of Squares & df & Mean Square & F Value & $p$-Value Prob $>$ F \\
\hline Model & 895.77 & 14 & 63.98 & 21.13 & $<0.0001$ \\
A-Extraction temperature & 1.14 & 1 & 1.14 & 0.38 & 0.5492 \\
B-Solvent concentration & 0.66 & 1 & 0.66 & 0.22 & 0.6471 \\
C-Extraction time & 15.12 & 1 & 15.12 & 4.99 & 0.0423 \\
$D$-Liquid/solid ratio & 277.25 & 1 & 277.25 & 91.55 & $<0.0001$ \\
$A B$ & 23.06 & 1 & 23.06 & 7.62 & 0.0154 \\
$A C$ & 79.88 & 1 & 79.88 & 26.38 & 0.0002 \\
$A D$ & 21.02 & 1 & 21.02 & 6.94 & 0.0196 \\
$B C$ & 1.74 & 1 & 1.74 & 0.57 & 0.4616 \\
\hline
\end{tabular}


Table 3. Cont.

\begin{tabular}{cccccc}
\hline Source & Sum of Squares & df & Mean Square & F Value & $p$-Value Prob $>$ F \\
\hline$B D$ & 1.78 & 1 & 1.78 & 0.59 & 0.4557 \\
$C D$ & 10.40 & 1 & 10.40 & 3.43 & 0.0850 \\
$A^{2}$ & 306.19 & 1 & 306.19 & 101.10 & $<0.0001$ \\
$B^{2}$ & 37.53 & 1 & 37.53 & 12.39 & 0.0034 \\
$C^{2}$ & 123.97 & 1 & 123.97 & 40.94 & $<0.0001$ \\
$D^{2}$ & 194.65 & 1 & 194.65 & 64.27 & $<0.0001$ \\
Residual & 42.40 & 14 & 3.03 & & 0.1506 \\
Lack of Fit & 37.41 & 10 & 3.74 & 3.00 & not significant \\
Pure Error & 4.99 & 4 & 1.25 & & \\
Cor Total & 938.17 & 28 & & &
\end{tabular}

The $p$-value of this model was $<0.0001$, which indicated that the linear and quadratic terms were highly significant. The $p$-value of the lack of fit was $0.1506(>0.05)$, indicating that the experimental data adapted to the model.

Figure 2 shows that all residual-standard values were in \pm 3 intervals, indicating that the model was consistent with the experimental data with no error recorded [14].The precision was 15.292 (>4), indicating an adequate signal and the suitability of this model to be applied in navigation-design space. The "Pred R-Squared" of 0.7620 reasonably agreed with the "Adj R-Squared" of 0.9096. The "Adeq Precision" measures the signal-to-noise ratio, and a ratio greater than four is desirable. The ratio of 15.292 in this work indicated an adequate signal. Thus, this model can be used to navigate the design space.

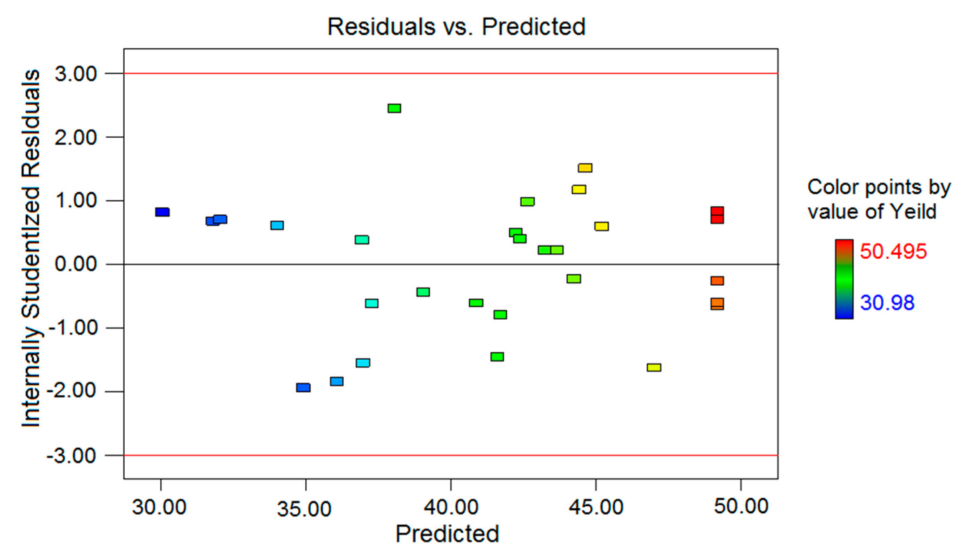

Figure 2. The studentized residuals and predicted response plot.

Figure 3A shows the contour plot for $\mathrm{Y}_{\mathrm{MLF}}$ as a function of various extraction temperatures and solvent concentrations at fixed extraction time (120.18 min) and liquid/solid ratio (34.60). The yield of MLF was found to increase rapidly with increased extraction temperature from $60{ }^{\circ} \mathrm{C}$ to $70{ }^{\circ} \mathrm{C}$, but decreased rapidly with increased extraction temperature beyond $70{ }^{\circ} \mathrm{C}$. Moreover, $\mathrm{Y}_{\mathrm{MLF}}$ increased with increased solvent concentration from $30 \%$ to $40 \%$ and then decreased from $40 \%$ to $50 \%$.

Figure $3 \mathrm{~B}$ shows the contour plot for $\mathrm{Y}_{\mathrm{MLF}}$ as a function of various extraction temperatures and extraction times at fixed solvent concentration (39.30\%) and liquid/solid ratio (34.60). The yield of MLF increased rapidly within the extraction temperature from $60^{\circ} \mathrm{C}$ to $70{ }^{\circ} \mathrm{C}$ and reached the maximum value. However, after $70{ }^{\circ} \mathrm{C}, \mathrm{Y}_{\mathrm{MLF}}$ did not increase and even decreased to a certain degree. The yield of MLF increased rapidly with the increase of extraction time from $90 \mathrm{~min}$ to $120 \mathrm{~min}$, and then decreased slightly from $120 \mathrm{~min}$ to $150 \mathrm{~min}$.

Figure 3C shows the contour plot for $\mathrm{Y}_{\mathrm{MLF}}$ as a function of various extraction temperatures and liquid/solid ratios at a fixed solvent concentration (39.30\%) and extraction time (120.18 min). The maximum $\mathrm{Y}_{\mathrm{MLF}}$ was obtained when the extraction temperature and liquid/solid ratio were $70{ }^{\circ} \mathrm{C}$ and 35 , respectively. 
Figure 3D shows the contour plot for $\mathrm{Y}_{\mathrm{MLF}}$ as a function of various solvent concentrations and extraction times at a fixed extraction temperature $\left(70.85^{\circ} \mathrm{C}\right)$ and liquid/solid ratio (34.60). The maximum $\mathrm{Y}_{\mathrm{MLF}}$ was achieved when solvent concentration and extraction time were $40 \%$ and 120 min, respectively.

Figure $3 \mathrm{E}$ shows the contour plots for $\mathrm{Y}_{\mathrm{MLF}}$ as a function of various solvent concentrations and liquid/solid ratios at a fixed extraction temperature $\left(70^{\circ} \mathrm{C}\right)$ and extraction time $(120 \mathrm{~min})$. The maximum $\mathrm{Y}_{\mathrm{MLF}}$ was achieved when the solvent concentration and liquid/solid ratio were 40 and 35 , respectively.

Figure $3 \mathrm{~F}$ shows the contour plot for $\mathrm{Y}_{\mathrm{MLF}}$ as a function of various extraction times and liquid/solid ratios at a fixed extraction temperature $\left(70{ }^{\circ} \mathrm{C}\right)$ and solvent concentration $(40 \%)$. The yield of MLF increased with prolonged extraction time from $90 \mathrm{~min}$ to $120 \mathrm{~min}$ and then decreased from $120 \mathrm{~min}$ to 150 min. Moreover, $Y_{M L F}$ increased rapidly with increased solvent concentration from $20 \%$ to $35 \%$ but decreased slightly beyond $35 \%$.

Overall, the optimal conditions for total flavonoids extraction from mulberry leaves were as follows: extraction temperature of $70.85^{\circ} \mathrm{C}$, solvent concentration of $39.30 \%$, extraction time of 120.18 $\mathrm{min}$, and liquid/solid ratio of 34.60:1. The predicted yield was $50.33 \mathrm{mg} \mathrm{g}^{-1}$. According to the quadratic polynomial model and the contour plot (Figure 3), the liquid/solid ratio was the most significant factor that influenced $\mathrm{Y}_{\mathrm{MLF}}$, followed by extraction time, extraction temperature, and solvent concentration.
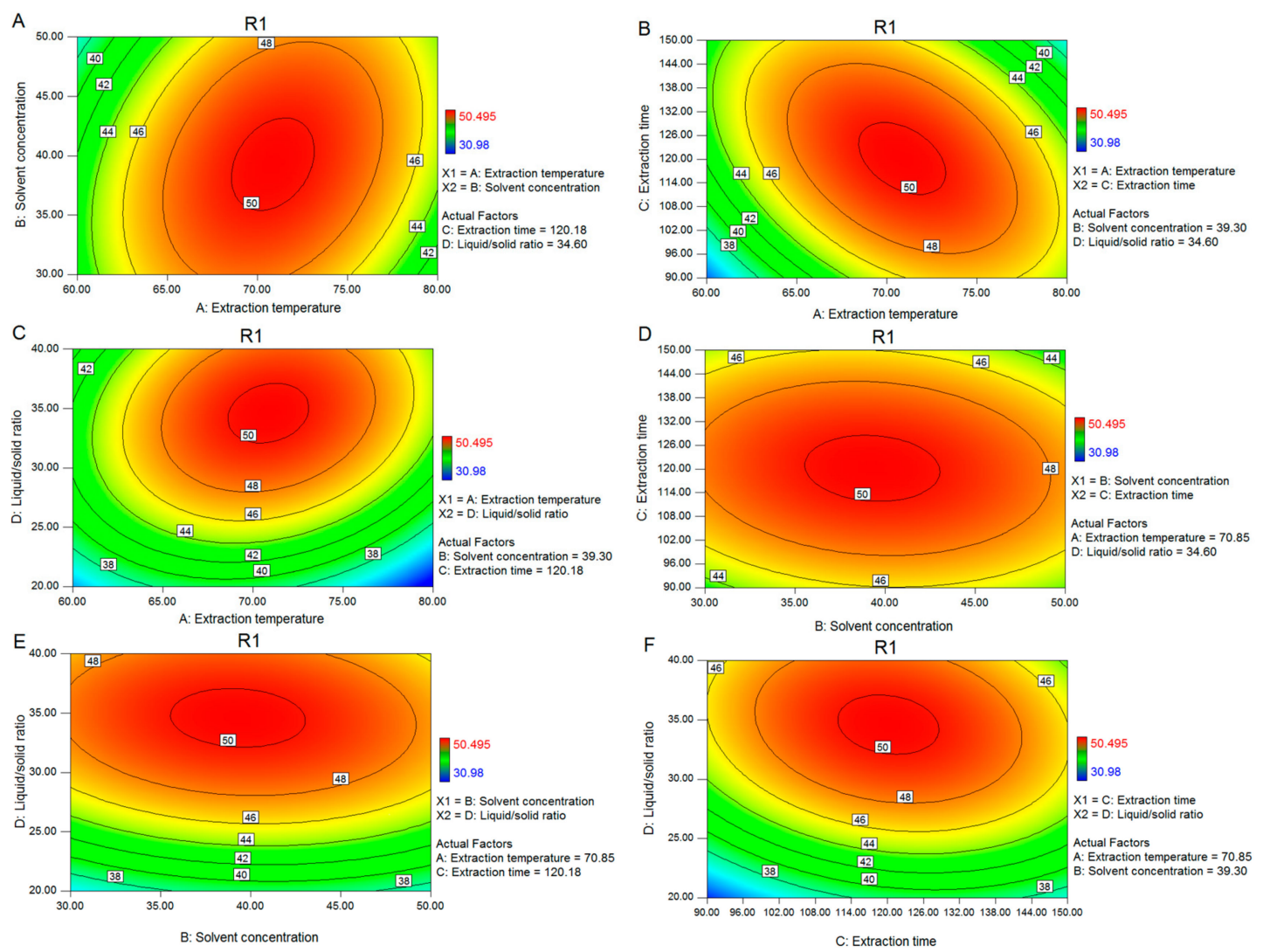

Figure 3. Contour plots showing the effects of the ratio of two single factors. (A) Extraction temperature $\left({ }^{\circ} \mathrm{C}\right)$ versus solvent concentration; $(\mathbf{B})$ extraction temperature $\left({ }^{\circ} \mathrm{C}\right)$ versus extraction time; $(\mathbf{C})$ extraction temperature $\left({ }^{\circ} \mathrm{C}\right)$ versus liquid/solid ratio; (D) solvent concentration versus extraction time; (E) solvent concentration versus liquid/solid ratio; (F) extraction time $(\mathrm{min})$ versus liquid/solid ratio concentration.

\subsection{Verification of Predictive Model}

The value predicted using the software was verified under selected optimal extraction conditions. The actual values were examined under the conditions determined from the RSM. The mean of actual 
values, i.e., $50.52 \mathrm{mg} \mathrm{g}^{-1}$, was in accordance with the predicted value indicating that the model was adequate for the extraction process.

\subsection{The Quantification of Extract of MLF with Different Solvent}

The $\mathrm{MLF}_{\mathrm{p}}, \mathrm{MLF}_{\mathrm{e}}$, and $\mathrm{MLF}_{\mathrm{b}}$ were generated by extraction of MLF with petroleum ether, ethyl acetate, and $n$-butanol, respectively. The MLF, MLF,$M_{\mathrm{p}} \mathrm{F}_{\mathrm{e}}$, and $\mathrm{MLF}_{\mathrm{b}}$ were quantified, and the content ratio of the flavonoids was 100:7.33:62:28.67. The total extraction rate of the flavonoids by three solvents was $98 \%$.

\subsection{Antimicrobial Activity}

Three kinds of microorganisms, namely, S.aureus, B.subtilis, and B.pumilus were selected to test the in vitro antibacterial activity of MLF, MLF,$M L F$, and $M_{\mathrm{p}} \mathrm{F}_{\mathrm{b}}$. The MIC was used to represent antimicrobial activity. As shown in Table 4, the MIC of MLF $\mathrm{e}_{\mathrm{e}}$ was of the lowest among all MLF samples.

Table 4. MIC of antibacterial activity results of MLF.

\begin{tabular}{cccc}
\hline & Staphylococcus aureus & Bacillus subtilis & Bacillus pumilus \\
\hline MLF $\left(\mu \mathrm{g} \mathrm{mL}^{-1}\right)$ & 30.24 & 30.24 & 18.14 \\
$\mathrm{MLF}_{\mathrm{p}}\left(\mu \mathrm{g} \mathrm{mL}^{-1}\right)$ & 50.40 & 140.00 & 50.40 \\
$\mathrm{MLF}_{\mathrm{e}}\left(\mu \mathrm{g} \mathrm{mL}^{-1}\right)$ & 3.92 & 10.89 & 6.53 \\
$\mathrm{MLF}_{\mathrm{b}}\left(\mu \mathrm{g} \mathrm{mL}^{-1}\right)$ & 50.40 & 84.00 & 30.24 \\
\hline
\end{tabular}

\subsection{In Vitro Antioxidant Activity}

The scavenging abilities for the 2,2'-azinobis-(3-ethylbenz-thiazoline-6-sulphonate) $\left(\mathrm{ABTS}^{+}\right.$) radical and 1,1-diphenyl-2-picrylhydrazyl (DPPH) radical, as well as the total reducing power, were selected to investigate the antioxidant activity of MLF in vitro, with vitamin C (VC) as the positive control. The antioxidant activity was characterized with the concentration of MLF samples that resulted in $50 \%$ of scavenging $\left(\mathrm{IC}_{50}\right)$ or effective concentration at which 0.5 absorbance units $\left(\mathrm{EC}_{50}\right)$ was observed.

As shown in Table 5, extraction of organic solvent with various polarities significantly affected the antioxidant activities in vitro. The $\mathrm{ABTS}^{+}$and $\mathrm{DPPH}$ radical-scavenging abilities and the total reducing power increased with increased concentration of MLF and VC from $20 \mu \mathrm{g} \mathrm{mL}^{-1}$ to $400 \mu \mathrm{g} \mathrm{mL}^{-1}$ and $25 \mu \mathrm{g} \mathrm{mL} \mathrm{L}^{-1}$ to $125 \mu \mathrm{g} \mathrm{mL}^{-1}$, respectively. The flavonoids extracted with ethyl acetate extracted MLF displayed the lowest $\mathrm{IC}_{50} / \mathrm{EC}_{50}$.

Table 5. The results of antioxidant in vitro of MLF samples and vitamin C (VC).

\begin{tabular}{cccc}
\hline & ABTS $^{+}\left(\mathbf{I C}_{50}\right)$ & DPPH $\left(\right.$ IC $\left._{50}\right)$ & Reducing Power EC $\left._{50}\right)$ \\
\hline MLF $\left(\mu \mathrm{g} \mathrm{mL}^{-1}\right)$ & $60.33 \pm 5.51^{\mathrm{a}}$ & $211.67 \pm 7.64^{\mathrm{a}}$ & $1126.67 \pm 64.29^{\mathrm{a}}$ \\
$\mathrm{MLF}_{\mathrm{p}}\left(\mu \mathrm{g} \mathrm{mL}^{-1}\right)$ & $642.33 \pm 11.24^{\mathrm{b}}$ & $2070.00 \pm 60.83^{\mathrm{b}}$ & $2429.33 \pm 112.88^{\mathrm{b}}$ \\
$\mathrm{MLF}_{\mathrm{e}}\left(\mu \mathrm{g} \mathrm{mL}^{-1}\right)$ & $32.73 \pm 1.07^{\mathrm{c}}$ & $145.00 \pm 13.23^{\mathrm{c}}$ & $868.67 \pm 18.04^{\mathrm{c}}$ \\
$\mathrm{MLF}_{\mathrm{b}}\left(\mu \mathrm{g} \mathrm{mL}^{-1}\right)$ & $44.33 \pm 6.03^{\mathrm{ac}}$ & $154.00 \pm 9.64^{\mathrm{c}}$ & $1760.00 \pm 52.92^{\mathrm{d}}$ \\
$\mathrm{VC}^{\mathrm{c}}\left(\mu \mathrm{g} \mathrm{mL}^{-1}\right)$ & $7.20 \pm 0.70^{\mathrm{d}}$ & $0.0047 \pm 0.00055^{\mathrm{d}}$ & $0.079 \pm 0.0032^{\mathrm{e}}$ \\
\hline a,b,c,d,e Same antioxidant system with different superscripts are significantly different $(p<0.05)$.
\end{tabular}

\section{7. $\alpha$-Amylase Inhibition Activity}

The $\alpha$-amylase inhibition activity of the MLF samples were tested and controlled with acarbose in the same concentration. Activity was evaluated with the value of $\mathrm{IC}_{50}$. As shown in Table 6 , the $\mathrm{IC}_{50}$ values of MLF, $\mathrm{MLF}_{\mathrm{p}}, \mathrm{MLF}_{\mathrm{e}}, \mathrm{MLF}_{\mathrm{b}}$, and acarbose were $125.00 \pm 10.00,356.67 \pm 16.07,88.00 \pm 3.61$, and $67.67 \pm 7.51 \mu \mathrm{g} \mathrm{mL}^{-1}$, respectively. 
Table 6. $\alpha$-Amylase inhabitation of the MLF.

\begin{tabular}{cc}
\hline & $\alpha$-Amylase Inhabitation Activity $\left(\mathrm{IC}_{\mathbf{5 0}}\right)$ \\
\hline MLF $\left(\mu \mathrm{g} \mathrm{mL}^{-1}\right)$ & $125.00 \pm 10.00^{\mathrm{a}}$ \\
$\mathrm{MLF}_{\mathrm{p}}\left(\mu \mathrm{g} \mathrm{mL}^{-1}\right)$ & $356.67 \pm 16.07^{\mathrm{b}}$ \\
$\mathrm{MLF}_{\mathrm{e}}\left(\mu \mathrm{g} \mathrm{mL}^{-1}\right)$ & $88.00 \pm 3.61^{\mathrm{c}}$ \\
$\mathrm{MLF}_{\mathrm{b}}\left(\mu \mathrm{g} \mathrm{mL}^{-1}\right)$ & $66.67 \pm 7.05^{\mathrm{d}}$ \\
Acarbose $\left(\mu \mathrm{g} \mathrm{mL}^{-1}\right)$ & $51.33 \pm 4.04^{\mathrm{e}}$ \\
\hline $\mathrm{a}, \mathrm{b}, \mathrm{d}, \mathrm{d}, \mathrm{e}$ & Different superscripts are significantly different $(p<0.05)$.
\end{tabular}

\subsection{AHP Model for Weight Calculation}

A multi-criterion model was developed to evaluate the related process parameters, and its structure is depicted in Figure 4. The AHP model consisted of two levels. The top level was the goal of the model (comprehensive assessment of the multiple-bioactivities of MLF samples), and the second level covered the criteria ( $f_{1}$, MIC of S.aureus antibacterial activity; $f_{2}$, MIC of B.subtilis antibacterial activity; $f_{3}$, MIC of B.pumilus antibacterial activity; $f_{4}, \mathrm{IC}_{50}$ of $\mathrm{ABTS}^{+}$radical-scavenging activity; $f_{5}$, $\mathrm{IC}_{50}$ of DPPH scavenging activity; $f_{6}, \mathrm{EC}_{50}$ of total reducing power; and $f_{7}, \mathrm{IC}_{50}$ of $\alpha$-amylase inhibition activity). The importance of criteria in the goal level was assessed using a suitable scale based on Table 7.

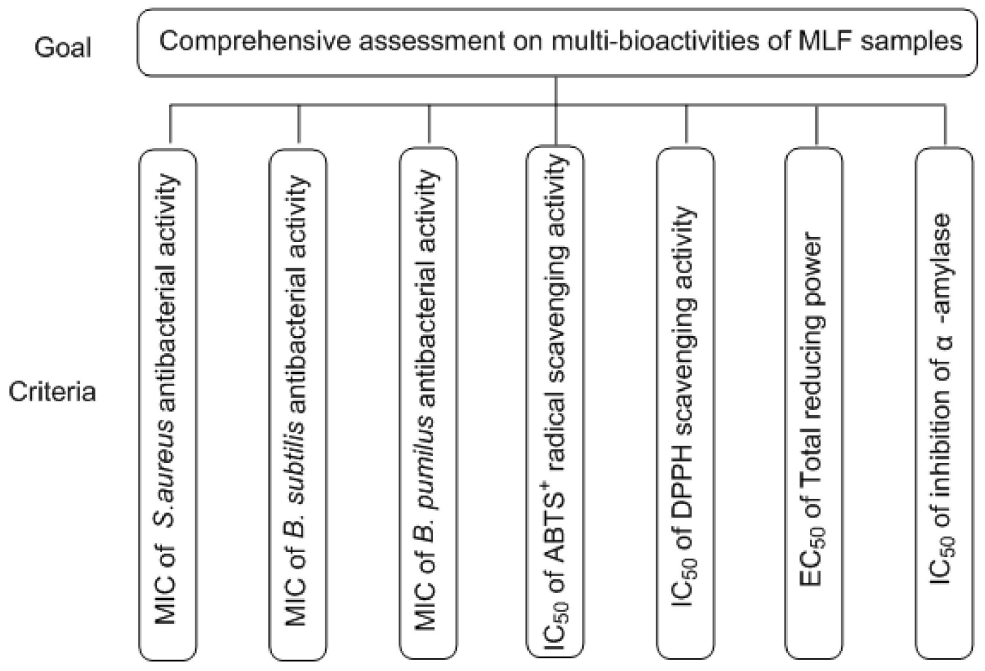

Figure 4. The proposed analytical hierarchy process model.

Table 7. Value meaning of the nine-scale method.

\begin{tabular}{cc}
\hline Description of $f_{i} / f_{j}$ & Scale \\
\hline$f_{i}$ is equally important as $f_{j}$ & 1 \\
$f_{i}$ is moderately more important than $f_{j}$ & 3 \\
$f_{i}$ is strongly more important than $f_{j}$ & 5 \\
$f_{i}$ is very strongly more important than $f_{j}$ & 7 \\
$f_{i}$ is extremely more important than $f_{j}$ & 9 \\
The median of adjacent scales, when a compromise is needed & $2,4,6,8$ \\
\hline
\end{tabular}


The results were then transformed into positive pairwise comparison matrices $\mathrm{N}$ as follows:

$$
\mathrm{N}=\left[\begin{array}{ccccccc}
1 & 2 & 2 & 3 & 3 & 3 & 5 \\
1 / 2 & 1 & 1 & 3 & 3 & 3 & 5 \\
1 / 2 & 1 & 1 & 3 & 3 & 3 & 5 \\
1 / 3 & 1 / 3 & 1 / 3 & 1 & 1 & 1 & 3 \\
1 / 3 & 1 / 3 & 1 / 3 & 1 & 1 & 1 & 3 \\
1 / 3 & 1 / 3 & 1 / 3 & 1 & 1 & 1 & 1 / 3 \\
1 / 5 & 1 / 5 & 1 / 5 & 1 / 3 & 1 / 3 & 3 & 1
\end{array}\right]
$$

The calculated initial weights $\mathrm{w}_{1^{\prime}}, \mathrm{w}_{2^{\prime}}, \mathrm{w}_{3^{\prime}}, \mathrm{w}_{4^{\prime}}, \mathrm{w}_{5^{\prime}}, \mathrm{w}_{6^{\prime}}$, and $\mathrm{w}_{7^{\prime}}$, were 2.4566, 1.8253, 1.8253, $0.7306,0.7306,0.5338$, and 0.4288 , respectively. In further normalized computation, the priority weights $\mathrm{w}_{1}, \mathrm{w}_{2}, \mathrm{w}_{3}, \mathrm{w}_{4}, \mathrm{w}_{5}, \mathrm{w}_{6}$, and $\mathrm{w}_{7}$ were $0.2880,0.2140,0.2140,0.0856,0.0856,0.0626$, and 0.0503 , respectively. The maximum eigenvalue $\left(\lambda_{\max }\right)$ was $7.5182, \mathrm{CI}$ was 0.0864 , the consistency ratio $(\mathrm{CR})$ was $0.0654<0.1$, and the consistency check was passed. The value of $w$, as the priority weight of criterion to goal, was provided as follows:

$$
\mathrm{N}=\left[\begin{array}{lllllll}
0.2880 & 0.2140 & 0.2140 & 0.0856 & 0.0856 & 0.0626 & 0.0503
\end{array}\right]
$$

The comprehensive assessment score $\mathrm{S}$ of $M L F, \mathrm{MLF}_{\mathrm{p}}, \mathrm{MLF}_{\mathrm{e}}$, and $\mathrm{MLF}_{\mathrm{b}}$ were 119.16, 457.45, 78.88, and 169.52 , respectively.

\subsection{Hemolysis Analysis}

The hemolysis property of MLF was evaluated with the absorbance of human red blood cells (hRBCs), which were treated with the $\mathrm{MLF}_{\mathrm{e}}$ and quantified in hemolyticrate. As described by Autian [15] and Yang [16], a sample does not have hemolysis property when its hemolyticrate is less than $5 \%$. As shown in Figure 5, MLF $\mathrm{e}_{\mathrm{e}}$ in the concentration range of $0.005-1 \mathrm{mg} \mathrm{mL}^{-1}$ had no hemolysis property. Within this range, $\mathrm{MLF}_{\mathrm{e}}$ exhibited antimicrobial activity, antioxidant activity, and $\alpha$-amylase inhibition activity. This finding suggested the safe application of $\mathrm{MLF}_{\mathrm{e}}$ in food and medical industries.

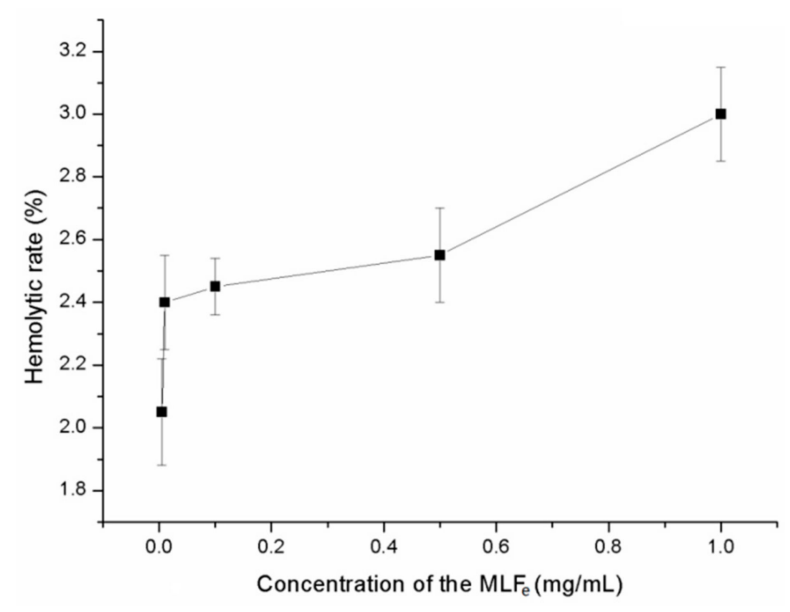

Figure 5. Hemolysis analysis of MLFe.

\section{Discussion}

Extraction temperature can surely influence the yield of flavonoids. The increase in temperature can lead to the enhancement of the diffusion rate of solvent and mass transfer, which can improve the dissolution of target compounds. High temperature further promotes the degradation of heat-labile substances. Given the high solubility of flavonoids in ethanol, it was used as an extraction solvent. The extraction time is also an essential factor affecting the extraction yield of compounds [17]. With 
prolonged extraction time, the yield does not reach its peak value until balance is achieved among the target compounds formed in the extraction system inhabitation and then becomes steady [18]. The liquid/solid ratio is a crucial element as well in the process of extraction. A higher solvent amount corresponds with higher yield, although solvent waste may ensue. In the present work, the extraction temperature, ethanol concentration, extraction time, and liquid/solid ratio were optimized by RSM and found to be $70.85^{\circ} \mathrm{C}, 39.30 \%, 120.18 \mathrm{~min}$, and 34.6:1, respectively. The actual yield of MLF was $50.52 \mathrm{mg} \mathrm{g}^{-1}$. This result may be due to the multiple impacts of all extraction conditions. No ultimate extraction process existed, as the different combinations of extraction conditions lead to different yields. In Mu's [19] study, the optimized extraction process by RSM were as follows: an extraction temperature of $68{ }^{\circ} \mathrm{C}$, extraction time of $40 \mathrm{~min}$, ethanol concentration of $52 \%$, and liquid/solid of 86 ; the yield of mulberry leaf flavonoids was $47.10 \mathrm{mg} \mathrm{g}^{-1}$. Huang [20] obtained a mulberry leaf flavonoid yield of $50.2 \mathrm{mg} \mathrm{g}^{-1}$ under the following optimized conditions: temperature, $\left(60^{\circ} \mathrm{C}\right)$; solid/liquid ratio, $(1: 14)$; ethanol concentration, (70\%); extraction time, (90 min); and number of extractions, 2 . In the current study, we obtained the optimized conditions with the minimum ethanol concentration and reasonable liquid/solid ratio, extraction temperature, and extraction time. The yield reached $50.52 \mathrm{mg} \mathrm{g}^{-1}$, which was highly suitable for actual production.

The ethanol extract of mulberry leaves contained four flavonoids, and their contents followed the order quercetin 3-(6-malonylglucoside) $>$ rutin $>$ isoquercitrin $>$ astragalin [4]. These flavonoids are well known to have multiple-bioactivities, including antimicrobial, antioxidant, and $\alpha$-amylase inhibition activity. After treatment with quercetin 3-(6-malonylglucoside), the thiobarbituric acid reactive substances concentrations significantly decreased by $20 \%$ in the liver of mice [21]. Rutin exhibited potent activity against $S$. aureus and B. cereus, with MIC values of 0.07 and $0.03 \mathrm{mg} \mathrm{mL}^{-1}$, respectively [22]. Moreover, the consumption of rutin reduced oxidative stress and glutathione disulfide content, as well as enhanced the levels of glutathione, glutathione peroxidase, glutathione reductase, and glutathione S-transferase in the hepatic tissue of rats with high-fat diet -induced obesity [23]. In vitro, $\mathrm{EC}_{50}$ for the DPPH radical scavenging of rutin was $15.7 \mu \mathrm{g}$, which approached that of the positive control BHA $(9.5 \mu \mathrm{g})$ [24]. Isoquercitrin exhibited antioxidant activity in DPPH radical scavenging $\left(\mathrm{IC}_{50}=11.8 \mu \mathrm{g} \mathrm{mL}{ }^{-1}\right)$ [25]. Astragalin possessed antioxidant activities for DPPH radical-scavenging activities $\left(\mathrm{FSC}_{50}=408.00 \mu \mathrm{mol} \mathrm{L}^{-1}\right.$ ) and reactive oxygen species scavenging activities $\left(\mathrm{OSC}_{50}=8.55 \mu \mathrm{mol} \mathrm{L}{ }^{-1}\right)$. Quercetin, isoquercetin, and rutin can inhibit the activity of $\alpha$-amylase by binding together in the competitive type [26]. Flavonoids also exhibited good cell-protection effects, for instance, astragalin $\left(1-50 \mu \mathrm{mol} \mathrm{L}^{-1}\right)$ had a half-time $46-90.3 \mathrm{~min}$ in hemolysis [27].

The activities of materials with multiple-bioactivities are difficult to evaluate. In the present work, AHP was introduced to calculate the priority weight of bioactivities. As the comprehensive assessment score $S$ is calculated based on the MIC and $\mathrm{IC}_{50}$ values, the low $S$ value represented excellent properties. Quercetin 3-(6-malonylglucoside), isoquercitrin, and rutin are highly soluble in ethyl acetate, which explains the antioxidant activity in different plant extracts, including lotus leaf, Trichosanthis seme, and Ipomoea batatas L. [28-30]. Here, the MLF $\mathrm{e}_{\mathrm{e}}$ content of flavonovids in $\mathrm{MLF}_{\mathrm{e}}$ reached to $62 \%$ of the MLF and exhibited multiple-bioactivities and its comprehensive assessment score $\mathrm{S}$ was $78.88 \mu \mathrm{g} \mathrm{mL}^{-1}$, which was the highest among all MLF samples. The $\mathrm{MLF}_{\mathrm{e}}$ at a concentration of $1.0 \mathrm{mg} \mathrm{mL}^{-1}$ exhibited no hemolysis property, which indicated the safe application of MLF in the food industry.

\section{Materials and Methods}

\subsection{Materials and Microbials}

Mulberry has been cultivated in Changbaishan for 20 years to accommodate the cold weather. After the first frost, the mulberry leaves were harvested in October 2017 in Jiaohe, Jilin Province and then dried in the shade after washing with distilled water. The dried leaves were pounded in mortars, sifted through a 200 mush sieve, and stored at $4{ }^{\circ} \mathrm{C}$. The rutin standard (code: 100080-201610) was 
purchased from the National Institute for the Control of Pharmaceutical and Biological Products. All other chemicals and reagents were analytical grade. Staphylococcus aureus ATCC 29213, B.subtilis ATCC 6633, and B.pumilus ATCC 700,814 were purchased from Beijing zhongke quality inspection biotechnology co., LTD (Beijing, China). Healthy hRBCs were obtained from the Red Cross Center for Blood, Jilin, China, which is responsible for the legal administration of human erythrocytes for clinical and scientific usage in Jilin.

\subsection{Experimental Design and Statistical Analysis}

We assumed that the four factors did not influence one another and selected extraction temperature $\left({ }^{\circ} \mathrm{C}, A\right)$, solvent concentration $(B)$, extraction time $(\mathrm{min}, C)$, and liquid/solid ratio $(D)$ as the signal factors to evaluate their effects on extraction. Seven grams of sample was extracted by hot-reflux method following the conditions in Table 8 . The resulting extract was concentrated in rotary evaporators and then in a vacuum drier.

Table 8. The extraction conditions of single element test.

\begin{tabular}{ccccc}
\hline & $\begin{array}{c}\text { Ethanol } \\
\text { Concentration }\end{array}$ & Liquid/Solid Ratio & $\begin{array}{c}\text { Extraction } \\
\text { Temperature }\end{array}$ & Extraction Time \\
\hline $\begin{array}{c}\text { Ethanol } \\
\text { concentration }\end{array}$ & $\begin{array}{c}20 \%, 30 \%, 40 \%, \\
50 \%, 60 \%\end{array}$ & $30: 1$ & $70{ }^{\circ} \mathrm{C}$ & $90 \mathrm{~min}$ \\
Liquid/solid ratio & $70 \%$ & $10: 1,20: 1,30: 1,40: 1$, & $60{ }^{\circ} \mathrm{C}$ & $90 \mathrm{~min}$ \\
$\begin{array}{c}\text { Extraction } \\
\text { temperature }\end{array}$ & $70 \%$ & $50: 1$ & $40,50,60,70,80^{\circ} \mathrm{C}$ & $90 \mathrm{~min}$ \\
Extraction time & $50 \%$ & $20: 1$ & $70{ }^{\circ} \mathrm{C}$ & $60,90,120,150,180$ \\
min
\end{tabular}

Based on the results of signal-factor experiments, a four-variable, three-level Box-Behnken Design (BBD) was designed with Design-Expert 8.0.6.1 software (Stat-Ease, Inc, Minneapolis, MN, USA) to optimize the extraction. Twenty-nine experimental runs of data were included, and five replicates at the center points were used to evaluate the experimental error and calculate the method repeat ability $[31,32]$. Second-order polynomial models were developed using the equation as below:

$$
Y=\beta_{0}+\sum_{\mathrm{i}=1}^{\mathrm{n}} \beta_{i} X_{i}+\sum_{\mathrm{i}=1}^{\mathrm{n}} \beta_{i i} X_{\mathrm{i}}^{2}+\sum_{\mathrm{i}<j}^{\mathrm{n}} \beta_{i j} X_{i} X_{j}+\varepsilon
$$

where $Y$ is the predicted extraction yield of MLF $\left(\mathrm{Y}_{\mathrm{MLF}}\right) ; \beta_{0}$ is the constant coefficient; $\beta_{i}, \beta_{i i}$, and $\beta_{i j}$ are the first-order, quadratic coefficients of $X_{i}$, and effect of interaction, respectively; and $\varepsilon$ is the experimental error (random). The experimental data were statistically tested by ANOVA through Duncan's multiple range tests with IBM SPSS, and the results are expressed as the mean \pm standard error; $p<0.05$ indicated significant effects.

After optimization, the adequacy of the model equation was validated by comparing the experimental data with the predicted results of the optimized model.

\subsection{Determination of Flavonoids Content}

The $\mathrm{NaNO}_{2}-\mathrm{Al}\left(\mathrm{NO}_{3}\right)_{3}-\mathrm{NaOH}$ colorimetric assay described by $\mathrm{Xu}$ [33] was used to determine the contents of flavonovids and rutin reference, and the spectrophotometer wavelength was set at $510 \mathrm{~nm}$. The yield (\%) was calculated as follows:

$$
\mathrm{Y}_{\mathrm{MLF}}(w / w)=\frac{\mathrm{W}_{\mathrm{MLF}}(\mathrm{mg})}{\mathrm{W}_{\mathrm{ML}}(\mathrm{g})}
$$


where $\mathrm{Y}_{\mathrm{MLF}}(w / w), \mathrm{W}_{\mathrm{MLF}}$, and $\mathrm{W}_{\mathrm{ML}}$ are the total flavonoid yield $(w / w)$, weight of flavonoids (mg), and weight of mulberry leaves $(\mathrm{g})$, respectively.

\subsection{Extract of MLF with Different Solvent}

Solvents such as petroleum ether, ethyl acetate, and n-butanol were used as extract solvents because of their different polarities. Ethanol extracts were extracted from the above solvents, allowing the components in the total flavonoids to be distributed in different solvents according to polarity. The MLF was extracted in organic solvent with various polarities, namely, $M_{\mathrm{p}}, \mathrm{MLF}_{\mathrm{e}}$, and $\mathrm{MLF}_{\mathrm{b}}$, based on the method described by $\mathrm{Xu}$ [30]. The extracts were concentrated, dried, weighed, quantified, and prepared with different concentrations.

\subsection{In Vitro Antibacterial Activity Assay}

In vitro antibacterial activity was represented with MIC. The micro-dilution method was used in the antibacterial (S.aureus, B. subtilis, and B. pumilus) experiments based on the method described by Cui [34]. Twenty microliters of different concentrations of the samples in $20 \%$ DMSO were mixed in a medium made with MLF at a final concentration of $0.50-200.00 \mu \mathrm{gmL}^{-1}$ in each well. Asolution containing $20 \%$ DMSO without MLF was used as a negative control, and 96well plates were placed in a biochemical incubator and cultivated for $24 \mathrm{~h}$.

\subsection{In Vitro Antioxidant Assay}

\subsection{1. $\mathrm{ABTS}^{+}$Radical-Scavenging Activity Test}

An $\mathrm{ABTS}^{+}$radical-scavenging capacity assay was performed as described by Cui [34]. A $1.0 \mathrm{~mL}$ mixture of different concentrations $\left(0.0125-1.35 \mathrm{mg} \mathrm{mL}^{-1}\right)$ of the samples and a $1.0 \mathrm{~mL}$ of diluted $\mathrm{ABTS}^{+}$radical solution were incubated for $10 \mathrm{~min}$ and subjected to absorbance measurement at $734 \mathrm{~nm}\left(A_{s}\right)$. The samples were replaced with distilled water in the blank system $\left(A_{0}\right)$, and VC was used as the positive control sample in concentrations of 1-9 $\mu \mathrm{g} \mathrm{mL}^{-1}$. The inhibition rate of ABTS radical scavenging of samples was calculated using the following formula:

$$
\mathrm{ABTS}^{+} \text {scavenging activity }(\%)=\frac{A_{0}-A_{s}}{A_{0}} \times 100 \%
$$

\subsubsection{DPPH Scavenging-Activity Test}

The DPPH scavenging-activity test was performed as described by Cui [34]. The MLF samples were dissolved in distilled water to different concentrations $\left(0.05-2.80 \mathrm{mg} \mathrm{mL}^{-1}\right)$. Two milliliters of diluted sample solution were mixed with $500 \mu \mathrm{L}$ of ethanol solution of DPPH $\left(0.2 \mathrm{~g} \mathrm{~L}^{-1}\right)$ and $1.0 \mathrm{~mL}$ of ethanol. After allowing standing for $30 \mathrm{~min}$ in darkness, the absorbance of the mixture was monitored at $517 \mathrm{~nm}\left(A_{s}\right)$. The test system containing DPPH solution without sample and containing ethanol without DPPH solution were used as a control $\left(A_{\mathcal{C}}\right)$ and blank $\left(A_{0}\right)$, respectively. Vitamin $C$ was used as a positive control at $1-9 \mu \mathrm{g} \mathrm{mL}^{-1}$. The DPPH radical-scavenging activity was calculated by the following equation:

$$
\text { DPPH radical scavenging activity }(\%)=\left[1-\frac{A_{S}-A_{C}}{A_{0}}\right] \times 100 \%
$$

\subsubsection{Total Reducing Power Test}

The total reducing power of the MLF samples was determined according to the method described by Cui [34]. Different flavonoids concentrations $\left(0.2-2.8 \mathrm{mg} \mathrm{mL}^{-1}\right)$ in $2 \mathrm{~mL}$ of $75 \%$ ethanol solution were mixed with PBS $\left(2 \mathrm{~mL}, 0.2 \mathrm{~mol} \mathrm{~L}^{-1}, \mathrm{pH} 6.6\right)$ and potassium ferricyanide $\left(\mathrm{K}_{3} \mathrm{Fe}(\mathrm{CN})_{6}\right)(2 \mathrm{~mL}, 1 \%)$. The mixture was incubated at $50{ }^{\circ} \mathrm{C}$ for $20 \mathrm{~min}$. Aliquots $(2 \mathrm{~mL})$ of trichloroacetic acid $(10 \%)$ were 
added to the mixture. The top layer of the solution $(2 \mathrm{~mL})$ was mixed with distilled water $(2 \mathrm{~mL})$ and $\mathrm{FeCl}_{3}(0.5 \mathrm{~mL}, 0.1 \%)$, and the absorbance was measured at $700 \mathrm{~nm}$ with a spectrophotometer. Increased absorbance of the reaction mixture indicated an increase in reduction capability. The concentrations of the positive control sample VC was set at $0.05-0.2 \mu \mathrm{g} \mathrm{mL}-1$.

\subsection{Inhibition of $\alpha$-Amylase Activity Assay}

The $\alpha$-amylase inhibition-activity assay of MLF samples was conducted based on the method described by Ali [35] with slight modifications. The MLF samples were diluted to different concentrations, i.e., $0.25-10 \mathrm{mg} \mathrm{mL}^{-1}$. Twenty microliters of the above sample solution were mixed in $20 \mu \mathrm{L}$ of $\alpha$-amylase solution, and then the mixture was incubated at $37^{\circ} \mathrm{C}$ for $10 \mathrm{~min}$. A forty microliter starch solution was added into the mixture followed by incubation at $37^{\circ} \mathrm{C}$ for $15 \mathrm{~min}$. The reaction was terminated by adding $20 \mu \mathrm{L}$ of hydrochloric acid. For coloring, $100 \mu \mathrm{L}$ of $\mathrm{I}_{2}-\mathrm{KI}$ solution was used to treat the mixture, and then the absorbance at $595 \mathrm{~nm}\left(A_{S}\right)$ was measured. The two other reaction systems with PBS replacing starch solution and sample were used as the control $\left(A_{c}\right)$ and blank $\left(A_{b}\right)$, respectively. In the positive-control groups, the samples were replaced with acarbose at $9.80-156.25 \mu \mathrm{g} \mathrm{mL}^{-1}$. The $\alpha$-amylase activity-inhibition rates were calculated by the following formula:

$$
\alpha-\text { amylase activityinhibitionrates }(\%)=\frac{A_{s}}{A_{c}-A_{b}} \times 100 \%
$$

\subsection{Calculation of Priority Weights by Analytic Hierarchy Process}

The priority weights of S.aureus antibacterial activity, B.subtilis antibacterial activity, B.pumilus antibacterial activity, $\mathrm{ABTS}^{+}$radical scavenging-activity, DPPH scavenging-activity, total reducing power, and inhibition of $\alpha$-amylase were calculated by AHP according to a reported method [36]. The evaluation target tree was initially established, and then a pairwise comparison matrix of the criteria was built. Results of the pairwise comparison were transformed into a positive pairwise comparison matrix $\mathrm{N}$ as follows:

$$
\mathrm{N}=\left[N_{i j}\right]_{n \times n}=\left[\begin{array}{cccc}
f_{1} / f_{1} & f_{1} / f_{2} & \cdots & f_{1} / f_{n} \\
f_{2} / f_{1} & f_{2} / f_{2} & \cdots & f_{2} / f_{n} \\
\vdots & \vdots & \vdots & \vdots \\
f_{n} / f_{1} & f_{n} / f_{2} & \cdots & f_{n} / f_{n}
\end{array}\right] i, j=1,2 \cdots n
$$

where $f_{i} / f_{j}$ represents the priority weights of factors $i$ and $j$. The weights were scored in nine possible scales, as shown in Table7.

The initial and normalized weight coefficient, $\mathrm{w}_{\mathrm{i}}{ }^{\prime}$ and $\mathrm{w}_{\mathrm{i}}$, were calculated as follows:

$$
\begin{gathered}
\mathrm{w}_{\mathrm{i}}^{\prime}=\sqrt[n]{f_{1} f_{2} \cdots \mathrm{f}_{\mathrm{n}}} \\
\mathrm{w}_{\mathrm{i}}=\frac{\mathrm{w}_{\mathrm{i}}^{\prime}}{\sum_{\mathrm{i}=1}^{\mathrm{n}} \mathrm{w}_{\mathrm{i}}^{\prime}}
\end{gathered}
$$

The consistency ratio (CR) of the pairwise matrix was used to evaluate the reasonability and calculated as follows:

$$
\begin{gathered}
\mathrm{CR}=\frac{\mathrm{CI}}{\mathrm{RI}} \\
\mathrm{CI}=\frac{\lambda_{\max }-\mathrm{n}}{\mathrm{n}-1} \\
\lambda_{\max }=1 / \mathrm{n} \sum_{\mathrm{i}=1}^{\mathrm{n}}\left(\sum_{\mathrm{j}=1}^{\mathrm{n}} f_{i j} \times \frac{\mathrm{w}_{\mathrm{j}}}{\mathrm{w}_{\mathrm{i}}}\right)
\end{gathered}
$$

where RI is the random consistency index whose value for computation is presented in Table 9 [37]. 
Table 9. The average consistencies of random matrices.

\begin{tabular}{cccccccccc}
\hline Matrix order & $\mathbf{1}$ & $\mathbf{2}$ & $\mathbf{3}$ & $\mathbf{4}$ & $\mathbf{5}$ & $\mathbf{6}$ & $\mathbf{7}$ & $\mathbf{8}$ & $\mathbf{9}$ \\
\hline $\begin{array}{c}\text { Random consistency } \\
\text { index }\end{array}$ & 0.00 & 0.00 & 0.58 & 0.90 & 1.12 & 1.24 & 1.32 & 1.41 & 1.45 \\
\hline
\end{tabular}

If $C R \leq 0.1$, the evaluation within the matrix was acceptable. The normalized weight coefficient was then used to comprehensively assess the multiple-bioactivities of the MLF samples; if CR > 0.1, the judgment was "untrustworthy". The comprehensive-assessment score of the multiple-bioactivities was measured as S:

$$
\mathrm{S}=\sum_{\mathrm{i}=1}^{\mathrm{n}} f_{i} \times \mathrm{wi}
$$

\subsection{The Hemolytic Examination of Flavonoids}

The hemolytic test was performed per the description of the Chinese Pharmacopoeia. Thirty microliters of different concentrations of $\mathrm{MLF}_{\mathrm{e}}$ were added into amixture of $250 \mu \mathrm{L}$ of $2 \% \mathrm{hRBC}$ suspension, and $220 \mu \mathrm{L}$ of $0.9 \% \mathrm{NaCl}$ solution was added to the $\mathrm{MLF}_{\mathrm{e}}$ until the final concentrations of $5,10,100,500$, and $1000 \mathrm{mg} \mathrm{mL}^{-1}$ were reached. The system was incubated at $37^{\circ} \mathrm{C}$ for $1 \mathrm{~h}$ and centrifuged at $1000 \mathrm{r} \mathrm{min}^{-1}$ for $10 \mathrm{~min}$. One hundred microliters of supernatant were transferred onto a 96well plate, and the absorbance was measured at $540 \mathrm{~nm}\left(A_{M L F e}\right)$ with Molecular Devices, LLC Spectra Max ${ }^{\circledR}$ M4 (Sunnyvale, CA, USA). The system without MLF $_{e}$, which was replaced with the same volume $0.9 \% \mathrm{NaCl}$ solution, was set as the negative control $\left(A_{N}\right)$. The system contained $250 \mu \mathrm{L}$ of $2 \%$ hRBC suspension, and $250 \mu \mathrm{L}$ of distilled water was set as the positive control $\left(A_{P}\right)$. Amixture of $470 \mu \mathrm{L}$ of $0.9 \% \mathrm{NaCl}$ solution and $30 \mu \mathrm{L}$ of $\mathrm{MLF}_{\mathrm{e}}$ sample was set as the background $\left(A_{B}\right)$. The tests were run in triplicate. Data were expressed as the mean \pm standard deviation. The hemolyticrate was calculated with the following formula:

$$
\text { Hemolytic rate }=\frac{A_{M L F e}-A_{N}-A_{B}}{A_{P}-A_{N}}
$$

\subsection{Statistical Analysis}

All assays were performed in triplicate. The experimental data were statistically tested by ANOVA through Duncan's multiple-range tests by using SPSS statistical software version 19.0 (SPSS Inc, Chicago, IL, USA). Results are expressed as the mean \pm standard error; $p<0.05$ indicated significant effects.

\section{Conclusions}

The extraction conditions of MLF were optimized by BBD and found to be as follows: extraction temperature of $70.85^{\circ} \mathrm{C}$, solvent concentration of $39.30 \%$, extraction time of $120.18 \mathrm{~min}$, and liquid/solid ratio of 34.60:1. The yield under these optimized conditions was $50.52 \mathrm{mg} \mathrm{g}^{-1}$. The good antimicrobial, antioxidant, and $\alpha$-amylase inhibition activity of $\mathrm{MLF}_{\mathrm{e}}$ suggested its potential usage in the food industry, such as a meat preservative, or in the drug industry, such as antibacterial and hypoglycemic agents. No hemolysis property was observed at $1 \mathrm{mg} \mathrm{mL} \mathrm{m}^{-1}$, which was higher than the working concentration, thereby indicating the safety application of $\mathrm{MLF}_{\mathrm{e}}$.

Author Contributions: Conceptualization, H.C. and X.Z.; methodology, Y.Z.; software, Y.D.; validation, Y.Z.; formal analysis, M.W.; investigation, T.L.; resources, X.Z.; data curation, H.C.; writing — original draft preparation, H.C. and H.Z.; writing - review and editing, X.Y.; visualization, H.-L.Z.; supervision, Y.D.; project administration, H.-L.Z.; funding acquisition, T.L.

Funding: This research was funded by the 13th Five-Year Plan Science and Technology Project of Jilin Provincial Department of Education, grant number JJKH20180546KJ, and the Technology Bureau of Jilin City, grant number 201750204.

Conflicts of Interest: The authors declare no conflict of interest. 


\section{References}

1. Vichasilp, C.; Nakagawa, K.; Sookwong, P.; Suzuki, Y.; Kimura, F.; Higuchi, O.; Miyazawa, T. Optimization of 1-deoxynojirimycin extraction from mulberry leaves by using response surface methodology. Biosci. Biotechnol. Biochem. 2009, 73, 2684-2689. [CrossRef] [PubMed]

2. Han, R.M.; Zhang, J.P.; Skibsted, L.H. Reaction dynamics of flavonoids and carotenoids as antioxidants. Molecules 2012, 17, 2140-2160. [CrossRef] [PubMed]

3. Li, W.; Li, T.; Tang, K. Flavonoids from mulberry leaves by microwave-assisted extract and anti-fatigue activity. Nurs. Clin. North Am. 2009, 40, 898-902.

4. Katsube, T.; Imawaka, N.; Kawano, Y.; Yamazaki, Y.; Shiwaku, K.; Yamane, Y. Antioxidant flavonol glycosides in mulberry (Morus alba L.) leaves isolated based on LDL antioxidant activity. Food Chem. 2006, 97, $25-31$. [CrossRef]

5. Kim, G.N.; Jang, H.D. Flavonol content in the water extract of the mulberry (Morus alba L.) leaf and their antioxidant capacities. J. Food Sci. 2011, 76, 869-873. [CrossRef] [PubMed]

6. Liu, H.; Mou, Y.; Zhao, J.; Wang, J.; Zhou, L.; Wang, M.; Wang, D.; Han, J.; Yu, Z.; Yang, F. Flavonoids from Halostachys caspica and their antimicrobial and antioxidant activities. Molecules 2010, 15, 7933-7945. [CrossRef] [PubMed]

7. Santas, J.; Almajano, M.P.; Carbó, R. Antimicrobial and antioxidant activity of crude onion (Allium cepa, L.) extracts. Int. J. Food Sci. Technol. 2010, 45, 403-409. [CrossRef]

8. Tadera, K.; Minami, Y.; Takamatsu, K.; Matsuoka, T. Inhibition of $\alpha$-glucosidase and $\alpha$-amylase by flavonoids. J. Nutr. Sci. Vitaminol. 2007, 52, 149-153. [CrossRef]

9. Lo, P.E.; Scheib, H.; Frei, N.; Williamson, G.; Grigorov, M.; Chou, C.J. Flavonoids for controlling starch digestion: Structural requirements for inhibiting human alpha-amylase. J. Med. Chem. 2008, 51, 3555-3561.

10. Zhang, H.W.; Chen, X.Y.; Ling, C.Y. Optimization of alcoholic extraction of flavonoids from mulberry leaves using response surface methodology. Amino Acids Biotic Resour. 2010, 34, 76-79.

11. Wang, F.; Qiao, L.; Dan, X.Y.; Chu, F.J. Study on extraction and anti-oxidation of flavonoids from Morus alba L. leaves. Guangdong Agric. Sci. 2011, 15, 76-79.

12. Saaty, T.L. The Analytic Hierarchy Process. McGraw-Hill: New York, NY, USA, 1980; pp. 1-118.

13. Herva, M.; Roca, E. Review of combined approaches and multi-criteria analysis for corporate environmental evaluation. J. Clean. Prod. 2013, 39, 355-371. [CrossRef]

14. Hasni, K.; Ilham, Z.; Dharma, S.; Varman, M. Optimization of biodiesel production from Brucea javanica, seeds oil as novel non-edible feedstock using response surface methodology. Energy Convers. Manage. 2017, 149, 392-400. [CrossRef]

15. Autian, J. Biological model systems for the testing of the toxicity of biomaterials. Polym. Med. Surg. 1975, 8 , 181-203.

16. Yang, X.C.; Niu, Y.L.; Zhao, N.N.; Mao, C.; Xu, F.J. A biocleavable pullulan-based vector via atrp for liver cell-targeting gene delivery. Biomaterials 2014, 35, 3873-3884. [CrossRef]

17. Galhiane, M.S.; Rissato, S.R.; Chierice, G.O.; Almeida, M.V.; Silva, L.C. Influence of different extraction methods on the yield and linalool content of the extracts of Eugenia uniflora L. Talanta 2006, 70, 286-292. [CrossRef] [PubMed]

18. Dong, J.; Liu, Y.; Liang, Z.; Wang, W. Investigation on ultrasound-assisted extraction of salvianolic acid B from Salvia miltiorrhiza root. Ultrason. Sonochem. 2010, 17, 61-65. [CrossRef]

19. Mu, H.R.; Chen, K.; Wang, X.L.; Liu, Y.F.; Xin, X.D. Comparison of orthogonal design and response surface methodology used to optimization of flavonoids extraction from mulberry leaves. J. Jiangsu Univ. Sci. Technol. 2016, 30, 80-93.

20. Huang, Q. Optimization of Extraction Process of Flavonoids from Mulberry Leaves. Food Res. Dev. 2016, 37, 81-84.

21. Takuya, K.; Masayuki, Y.; Kuninori, S.; Tomoko, I.; Ichiro, M.; Keiko, A.; Yukikazu, Y. Effect of flavonol glycoside in mulberry (Morus alba L.) leaf on glucose metabolism and oxidative stress in liver in diet-induced obese mice. J. Sci. Food Agric. 2010, 90, 2386-2392.

22. Singh, M.; Govindarajan, R.; Rawat, A.K.S.; Khare, P.B. Antimicrobial flavonoid rutin from Pteris vittata L. against pathogenic Gastrointestinal microflora. Am. Fern J. 2008, 98, 98-103. [CrossRef] 
23. Chinlin, H.; Wu, C.H.; Huang, S.L.; Gowchin, Y. Phenolic compounds rutin and o-coumaric acid ameliorate obesity induced by high-fat diet in rats. J. Agric. Food. Chem. 2009, 57, 425-431.

24. Kim, S.Y.; Gao, J.J.; Lee, W.C.; Ryu, K.S.; Lee, K.R.; Kim, Y.C. Antioxidative flavonoids from the leaves of Morus alba. Arch. Pharm. Res. 1999, 22, 81-85. [CrossRef]

25. Silva, C.G.; Raulino, R.J.; Cerqueira, D.M.; Mannarino, S.C.; Pereira, M.D.; Panek, A.D.; Silva, J.F.M.; Menezes, F.S.; Eleutherio, E.C.A. In vitro and in vivo determination of antioxidant activity and mode of action of isoquercitrin and Hyptis fasciculata. Phytomedicine 2009, 16, 761-767. [CrossRef] [PubMed]

26. Li, Y.; Gao, F.; Gao, F.; Shan, F.; Bian, J.; Zhao, C. Study on the interaction between 3 flavonoid compounds and alpha-amylase by fluorescence spectroscopy and enzymatic kinetics. J. Food Sci. 2010, 74, C199-C203. [CrossRef] [PubMed]

27. Park, S.N.; Sun, Y.K.; Lim, G.N.; Na, R.J.; Min, H.L. In vitro, skin permeation and cellular protective effects of flavonoids isolated from Suaeda asparagoides extracts. J. Ind. Eng. Chem. 2012, 18, 680-683. [CrossRef]

28. Zhang, L.; Wang, H.H.; Yan, S.H.; Tu, Z.C.; Li, J.; Chen, J.; Huang, Y.Z. Characterization of the chemical constituents in the ethyl acetate fraction of Lotus leaf by UPLC-QTOF-MS/MS. Food Sci. 2019. Available online: http://kns.cnki.net/kcms/detail/11.2206.TS.20190415.1617.010.html.

29. Liang, G.P.; Yang, J.; Liu, L.; Chen, R.H.; Ding, L.N.; Wan, L.P.; Chen, D.L. Study on $\alpha$-glucosidase inhibitory acticity and composition analysis of ethylcetate extract from introduced Trichosanthis Semen in Guizhou province. West. Chin. J. Pharm. Sci. 2019, 34, 109-114.

30. Xu, H.; Zhang, Z.; Gao, Y.; Zhang, J.; Dong, Y.; Cui, H. Determination of phenolic composition of active extracts from sweet potato leaves and their application in the preservation of chilled pork. Mod. Food Sci. Technol. 2018, 34, 149-157.

31. Liu, Z.; Mei, L.; Wang, Q.; Shao, Y.; Tao, Y. Optimization of subcritical fluid extraction of seed oil from Nitraria tangutorum, using response surface methodology. LWT Food Sci. Technol. 2014, 56, 168-174. [CrossRef]

32. Nyam, K.L.; Tan, C.P.; Lai, O.M.; Long, K.; Man, Y.B.C. Optimization of supercritical fluid extraction of phytosterol from roselle seeds with a central composite design model. Food Bioprod. Process. 2010, 88, $239-246$. [CrossRef]

33. $\mathrm{Xu}, \mathrm{G}$. Studies on the extracting and antioxidant activities of flavonoids in sweet potatoes. J. Food Sci. Biotechnol. 2007, 26, 22-27.

34. Cui, H.; Pan, H.W.; Wang, P.H.; Yang, X.D.; Zhai, W.C.; Dong, Y.; Zhou, H.L. Essential oils from Carex meyeriana Kunth: Optimization of hydrodistillation extraction by response surface methodology and evaluation of its antioxidant and antimicrobial activities. Ind. Crops Prod. 2018, 124, 669-676. [CrossRef]

35. Ali, H.; Houghton, P.J.; Soumyanath, A. Alpha-amylase inhibitory activity of some malaysian plants used to treat diabetes; with particular reference to Phyllanthus amarus. J. Ethnopharmacol. 2006, 107, 449-455. [CrossRef] [PubMed]

36. Fabjanowicz, M.; Bystrzanowska, M.; Namieśnik, J.; Tobiszewski, M.; Płotka-Wasylka, J. An analytical hierarchy process for selection of the optimal procedure for resveratrol determination in wine samples. Microchem. J. 2018, 142, 126-134. [CrossRef]

37. Jensen, R.E. An alternative scaling method for priorities in hierarchical structures. J. Math. Psychol. 1984, 28, 317-332. [CrossRef]

Sample Availability: Not available.

(C) 2019 by the authors. Licensee MDPI, Basel, Switzerland. This article is an open access article distributed under the terms and conditions of the Creative Commons Attribution (CC BY) license (http://creativecommons.org/licenses/by/4.0/). 